\title{
Relationship between exterior environment and quality characteristics of the traditional Gochujang produced in 2018 by eight regions in Korea
}

\author{
Seung-Yeon Baek ${ }^{1 \neq}$, Na-Young Gil ${ }^{1 \neq}$, Myeong-Hui Han ${ }^{1}$, Heui-Yun Kang ${ }^{2}$, \\ Ha-Yeon Lee ${ }^{3}$, Hyang-Sik Yoon ${ }^{4}$, Jeong Lee ${ }^{5}$, Young-Eun Song ${ }^{6}$, Sun-Kyung Lee ${ }^{7}$, \\ Jung-A Ryu ${ }^{8}$, Hyeon-Young Kim ${ }^{9}$, Soo-Hwan $\mathrm{Yeo}^{1}$, So-Young Kim ${ }^{1 *}$ \\ ${ }^{1}$ Fermented \& Processing Food Science Division, Department of Agrofood Resource, NIAS, RDA, Wanju 55365, Korea \\ ${ }^{2}$ Gyeonggi-do Agricultural Research \& Extension Services, Hwaseong 18388, Korea \\ ${ }^{3}$ Gangwondo Agricultural Research \& Extension Services, Chuncheon 24203, Korea \\ ${ }^{4}$ Chungcheongbuk-do Agricultural Research \& Extension Services, Cheongju 28130, Korea \\ ${ }^{5}$ Chungcheongnam-do Agricultural Research \& Extension Services, Yesan 32418, Korea \\ ${ }^{6}$ Jeonbuk Agricultural Research \& Extension Services, Iksan 54591, Korea \\ ${ }^{7}$ Jeollanamdo Agricultural Research \& Extension Services, Naju 58213, Korea \\ ${ }^{8}$ Gyeongsangbuk-do Agricultural Research \& Extension Services, Daegu 41404, Korea \\ ${ }^{9}$ Gyeongsangnam-do Agricultural Research \& Extension Services, Jinju 52733, Korea
}

\section{8년 한국의 8개 권역에서 전통 방식으로 제조한 고추장의 품질특성과 외부환경과의 상관관계}

\author{
백승연 ${ }^{1}$. 길나영 ${ }^{1} \cdot$ 한명희 $^{1} \cdot{\text { 강희 }^{2}}^{2} \cdot$ 이하연 $^{3} \cdot$ 윤향식 $^{4} \cdot$ 이정 $^{5} \cdot$ 송영 은 $^{6} \cdot$ 이선경 $^{7} \cdot$ 류정아 $^{8}$. \\ 김현영 ${ }^{9}$. 여수환 ${ }^{1}$. 김소영 ${ }^{1 *}$ \\ '농촌진흥청 국립농업과학원 농식품자원부 발효가공식품과, ${ }^{2}$ 경기도농업기술원, ${ }^{3}$ 강원도농업기술원, \\ 충청북도농업기술원, ${ }^{5}$ 충청남도농업기술원, ${ }^{6}$ 전라북도농업기술원, \\ 7전라남도농업기술원, ${ }^{8}$ 경상북도농업기술원, ${ }^{9}$ 경상남도농업기술원
}

\begin{abstract}
The objective of this study was to investigate the quality and environment properties of traditional Gochujang produced by 56 rural farms in 8 regions of Korea for evaluating the relationship between the components and environmental factors. Based on the regional means at the initiatory and after fermentation, the ranges of moisture content, salinity, pH, and acidity of Gochujang were determined to be from $46.87 \pm 7.09 \%$ to $43.80 \pm 7.17 \%$, from $7.52 \pm 2.21 \%$ to $8.53 \pm 2.57 \%$, from $5.01 \pm 0.30$ to $4.63 \pm 0.34$, and from $1.13 \pm 0.50 \%$ to $1.43 \pm 0.58 \%$, respectively. The mean contents of reducing sugar and amino-type nitrogen were from $16.46 \pm 7.63 \%$ to $20.48 \pm 7.57 \%$ and from $140.06 \pm 78.00 \mathrm{mg} \%$ to $198.68 \pm 87.11 \mathrm{mg} \%$, respectively. Hunter color values (L, a, and b) of Gochujang were from 26.16 \pm 9.27 to $22.49 \pm 9.02$, from $21.87 \pm 6.31$ to $20.14 \pm 7.58$, and from $19.43 \pm 11.94$ to $19.18 \pm 12.06$, respectively. Total aerobic number was increased from $6.50 \pm 1.29 \log \mathrm{CFU} / \mathrm{g}$ to $8.15 \pm 0.88 \mathrm{log} \mathrm{CFU} / \mathrm{g}$, while the fungal number was steadily decreased after fermentation. Next generation sequencing analysis to investigate the microbial communities revealed that
\end{abstract}

*Corresponding author. E-mail : foodksy@korea.kr

Phone : 82-63-238-3610, Fax : 82-63-238-3843

Received 10 October 2019; Revised 23 October 2019; Accepted 04 November 2019.

Copyright (c) The Korean Society of Food Preservation. All rights reserved.

\section{서 론}

전 세계적으로 지구 온난화 현상이 점차 심각해지고 있 어 2016년에는 전 지구 평균기온이 역대 최고로 높은 가운 데, 우리나라 역시 $13.6^{\circ} \mathrm{C}$ 로 평균기온이 평년 $\left(12.5^{\circ} \mathrm{C}\right)$ 보다 
the dominant bacteria in Gochujang belong to the phyla of Firmicutes and Cyanobacteria. Similarly, Aspergillus spp. of the phylum Ascomycota was the predominant fungi in traditional Gochujang. Finally, according to principle component analysis of the relationship between the quality and environmental properties of Gochujang, the contents of amino-type nitrogen, salinity, titratable acidity, and reducing sugar had strong correlations with exterior humidity. These results also suggest that the quality of traditional soybean sauces can be controlled by exterior environmental change.

Key words : traditional Gochujang, quality, microbial community, environment

$1.1^{\circ} \mathrm{C}$ 높아 1973 년 관측 이래 최고 기록을 나타내었는데 이는 2015-2016년 기간 동안 겨울철에 최고조로 발달한 엘니뇨가 약화되면서 그 영향이 지속되어 전 지구 평균기온 이 상승한 것으로 보고되었는데, 특히 한국의 온난화 현상 은 지구의 평균 온도 상승보다 2 배 빠르게 진행되고 있다고 하며, 이러한 현상은 지속적으로 진행될 것으로 예상되고 있다(1). 한편 전통 장류의 제조 및 품질은 온도, 습도 등의 외부 자연환경과 밀접한 관련성을 가지고 있어 이러한 환경 변화로 인하여 품질에도 영향을 줄 것으로 판단된다. 이에 한반도의 아열대 현상으로 인한 이상발효, 부패, 변색 등의 품질변화를 최소화하며 전통 장류를 안정적으로 생산하기 위해서는 환경변화에 따른 품질에 미치는 영향구명 및 제조 환경의 효율적 발효관리 방안 등의 해결책 마련을 위한 노력이 절실히 요구된다.

장류는 식품공전(2)의 식품별 기준 및 규격에서 동·식물 성 원료에 누룩균 등을 배양하거나 메주 등을 주원료로 하여 식염 등을 섞어 발효·숙성시킨 것을 제조·가공한 것으 로 정의하고 있고, 식품유형에 따라 한식메주, 개량메주, 한식간장, 양조간장, 산분해간장, 효소분해간장, 혼합간장, 한식된장, 된장, 고추장, 춘장, 청국장, 혼합장 등으로 나눠 져 있다(2). 이들 분류 중 고추장은 장류 중 두류 또는 곡류 등을 주원료로 하여 누룩균 등을 배양한 후 고춧가루 $6 \%$ 이상), 식염 등을 가하여 발효·숙성하거나 숙성 후 고춧가루 (6\% 이상), 식염 등을 가한 것으로 설명되어 있는데, 간장과 된장에 비해 고추장의 유형은 세분화되어 있지 않은 실정이 다(2). 또한, 전통식품 표준규격(3)에서는 고추장의 적용범 위를 전통적인 방법으로 성형 제조한 메주를 발효원으로 하고, 숙성 전에 고춧가루와 찹쌀, 멥쌀 및 보리쌀 등의 전분질원, 메주가루, 식염 등을 혼합하여 담근 고추장에 대하여 규정하고 있다(3).

고추장은 간장, 된장 등과 함께 우리 고유의 전통발효식 품으로, 찹쌀, 엿기름 등 탄수화물의 가수분해로 생긴 단맛 과 콩 단백질의 가수분해로 생성되는 아미노산의 감칠맛, 고추의 매운맛, 소금의 짠맛이 잘 조화를 이룬 복합 조미료 이자 기호식품이다(4,5). Hwang 등(6)의 보고와 같이 다른 장류에 비해 꾸준하게 소비자들에게 관심을 받고 있는 고추 장은 기호적인 측면 외에도 비만억제, 항암효과, 항변이원 성 및 항산화성 등과 같은 다양한 생리활성도 보고되었다
$(7,8)$.

현재 고추장의 제품개발 방향은 과거의 색, 맛, 향기 등의 관능적 품질 특성 향상 연구에서 식염의 과잉 섭취를 줄이 기 위해 저식염 고추장 및 다양한 기능성 소재 첨가에 의한 기능성 향상을 중시하는 경향으로 바뀌고 있다 $(9,10)$. 특히 많은 연구자들에 의해 보고된 바에 따르면 유산균 발효 다시마 분말(11), 겨자나 키토산(12), 구기자(13), 오미자박 분말(14) 등의 기능성 소재들을 활용하여 고추장을 제조한 연구결과도 있다(15). 이 밖에도 고추장의 저장성 연장, 저 장 - 유통기간 예측 등에 관한 연구들도 이루어졌다 $(16,17)$. 그러나 고추장의 다양한 상품개발을 위한 연구 외에 외부의 제조환경변화에 따른 전통식 고추장의 품질 및 미생물학적 변화를 보고한 연구 사례는 거의 없었다. 최근 이상고온으 로 인하여 실외에서 전통식 제조방법으로 제조하는 장류식 품의 발효, 숙성관리의 어려움과 함께 품질 변화에 대한 우려가 높은 실정이다.

따라서 본 연구에서는 2018년도에 각 권역별 전통식 제 조방법으로 고추장을 생산하는 업체를 선정하여 연중 고추 장의 품질특성 및 외부환경 변화를 측정하고, 지역 및 발효 기간에 따른 미생물 군집 변화를 살펴보기 위하여 차세대 염기서열 분석법(NGS)을 통해 주요 미생물의 변화를 측정 하였으며, 이들 변화들 간의 상관성과 지역별 또는 환경별 전통식 고추장의 품질변화를 예측할 수 있는 품질지표를 개발하고자 수행하였다.

\section{재료 및 방법}

\section{실험재료}

본 실험에 사용된 고추장 시료들은 전국 8 개 권역에서 2018년에 담근 후 1년간 숙성한 소규모 농가형 전통식 고추 장이었다. 고추장 시료들을 제조할 때 사용한 쌀, 콩, 소금, 고춧가루 등 주원료가 반드시 국산 원료이어야 하고, 설탕, 착색료 등 식품첨가물을 사용하지 않아야하며, 전통식품 및 대한민국 식품명인 등 인증제품을 우선적으로 고려하여 선정하였다. 전국을 경기도, 강원도, 충청남·북도, 전라 남 - 북도, 경상남 - 북도의 8 개 권역으로 구분하고, 권역별 7 개 업체로 부터 총 56 개 고추장 시료를 선정하여 발효기간 $0,3,6,12$ 개월 동안 4 차례 시료를 채취하여 사용하였다. 
이들 시료들은 품질특성 조사를 위해 $4{ }^{\circ} \mathrm{C}$ 에서 보관하며 사용하였다.

\section{수분 및 염도}

고추장의 수분 함량은 $\mathrm{AOAC}$ 법(18)을 따르되 일부 변형 하여 $105^{\circ} \mathrm{C}$ 상압가열건조법에 의해 분석하였으며, 고추장 $2 \mathrm{~g}$ 을 $105^{\circ} \mathrm{C}$ dry oven(MOV-112, Sanyo Co., Ltd., Osaka, Japan)에서 항량이 될 때까지 건조시켜 측정한 후 백분율 (\%)로 나타내었다.

염도는 $\mathrm{AgNO}_{3}$ 적정법(19)을 변형하여 측정하였다. 고추 장 $2.5 \mathrm{~g}$ 에 증류수로 20 배 희석하여 진탕배양기(SI-IS20 model, Shin-il Co., Seoul, Korea)에서 $500 \mathrm{rpm}, 1$ 시간 동안 추출 후 여과지(Whatman No.2)로 여과하고 이 여액 $10 \mathrm{~mL}$ 를 취하고 $5 \% \mathrm{~K}_{2} \mathrm{CrO}_{4}$ 지시약을 첨가하여 $0.1 \mathrm{~N} \mathrm{AgNO}_{3}$ 로 적정하여 적갈색이 될 때까지 적정하였다.

\section{$\mathrm{pH}$ 및 산도}

고추장의 $\mathrm{pH}$ 는 일정량 취한 시료에 증류수를 넣고 5 배 희석하여 Homogenizer(Polytron PT-MR 2100, Kinematica $\mathrm{AG}$, Lucerne, Swizerland)로 균질화한 후 8,000 rpm에서 10 분간 원심분리(Supra 25k, Hanil Co., Ltd., Incheon, Korea)한 상층액을 여과지(Whatman No.2)로 여과하여 시료액으로 사용하였다. 이 시료액을 pH meter(Corning 340, Corning Co., New York, NY, USA)로 분석하였다..

산도는 Choi 등(19)이 제시한 방법을 일부 변형하여 실시 하였다. $\mathrm{pH}$ 측정에 사용한 동일한 시료액 $5 \mathrm{~mL}$ 에 증류수 $20 \mathrm{~mL}$ 을 넣어 시료의 $\mathrm{pH}$ 가 8.3이 될 때까지 소비된 0.1 $\mathrm{N} \mathrm{NaOH}$ 의 양을 측정하였다.

\section{환원당 및 아미노태 질소}

고추장의 환원당 함량은 DNS법(20)에 따라 분석하였다. 시료액 $1 \mathrm{~mL}$ 에 DNS 시약 $3 \mathrm{~mL}$ 을 혼합하여 $100^{\circ} \mathrm{C}$ 의 물에서 5 분 동안 중탕한 것을 충분히 식힌 후 spectrophotometer (Libra S35, Biochrome Ltd., England)를 이용하여 $550 \mathrm{~nm}$ 에 서 흡광도를 측정하였다. Glucose를 표준물질로 하여 작성 한 검량곡선으로부터 상대적인 환원당 함량(\%)을 계산하 였다.

아미노태 질소( $\left.\mathrm{NO}_{3}-\mathrm{N}\right)$ 함량은 Formol법(21)을 일부 변 형하여 측정하였다. 고추장 시료액 $5 \mathrm{~mL}$ 에 중성 formalin(pH 8.3) $10 \mathrm{~mL}$ 과 3차 증류수 $10 \mathrm{~mL}$ 을 넣어 0.1 $\mathrm{N} \mathrm{NaOH}$ 로 $\mathrm{pH}$ 8.3이 될 때까지 중화하기 위해 적정하여 소모된 $0.1 \mathrm{~N} \mathrm{NaOH} \mathrm{mL}$ 양을 아미노태 질소 함량 $(\mathrm{mg} \%)$ 으 로 나타내었다.

\section{색 도}

고추장의 색도는 색도계(CSM-35SP, UltraScan PRO, Hunterlab, US)를 사용하여 측정한 후 Hunter scale의
$\mathrm{L}$ (lightness), a(redness), b(yellowness) 값으로 나타내었다. 이때 사용한 표준 백색판(standardplate)의 색도는 L(99.53), $\mathrm{a}(-0.12), \mathrm{b}(-0.13)$ 이었다(20).

\section{미생물 생균수}

고추장의 미생물 생균수는 Gil 등(20)의 방법에 의해서 조사되었다. 고추장 $1 \mathrm{~g}$ 에 $0.85 \%(\mathrm{w} / \mathrm{v})$ 생리식염수 $9 \mathrm{~mL}$ 을 시험관에 담아 균질화시키고 이를 십진희석법으로 희석하 여 총균수는 Tryptic Soy Agar(BD Difco, Detroit, MI, USA), 유산균수는 Lactobacilli MRS Agar(BD Difco, Detroit, MI, USA), 효모와 곰팡이는 $\mathrm{YM}(3 \mathrm{M}$ petrifilm, St. Paul, MN, USA), Bacillus cereus는 B. cereus base와 supplement (CHROMagar, Paris-France) 배지를 이용하여 접종 도말하 였다. 총균수는 $30^{\circ} \mathrm{C}$ 에서 24 시간 동안 호기배양, 유산균수 는 48-72시간 동안 혐기배양, 효모와 곰팡이는 72-96시간 동안, Bacillus cereus는 24-48시간 동안 호기배양한 후 형성 된 집락을 2회 반복 계수하여 $\log \mathrm{CFU} / \mathrm{g}$ 로 환산하여 표시하 였다.

미생물군집 분석(Next Generation Sequencing, NGS)

각 지역별 수집된 전통고추장으로부터 genomic DNA를 추출하기 위해 PowerMax® Soil DNA Isolation Kit(Cat. No. $12888, \mathrm{MO}$ BIO, Carlsbad, CA, USA)을 사용하였다. 추출된 genomic DNA의 정밀한 농도 측정을 위해 PicoGreen (Invitrogen, Carlsbad, CA, USA) 장비를 이용하여 DNA 농 도를 측정하였으며 최종 농도가 $1.0 \mathrm{ng} / \mathrm{ul}$ 이상이 되면 실험 에 사용하였다. 추출한 DNA에서 세균군집은 $16 \mathrm{~S} \mathrm{rRNA}$ 유전자의 V3-V4 region(약 $460 \mathrm{bp}$ )을 타켓으로 하는 primer set을 사용하여 증폭하였고, 진균군집은 Fungi ITS2 region 을 타켓으로 하는 primer set를 이용하여 PCR을 수행하였 다. 추출된 total genome DNA를 주형(template)으로 $16 \mathrm{~S}$ ribosomal DNA amplicon 및 ITS amplicon을 확보하기 위하 여 341F(TCGTCGGCAGCGTCAGATGTGTATAAGAGA CAGCCTACGGGNGGCWGCAG), 805R(GTCTCGTGGG CTCGGAGATGTGTATAAGAGACAGGACTACHVGGG TATCTATCC)을 기반으로 하는 bacterial primer와 ITS-3F(TCGTCGGCAGCGTCAGATGTGTATAAGAGA CAGGCATCGATGAAGAACGCAGC) 그리고 ITS-4R(G TCTCGTGGGCTCGGAGATGTGTATAAGAGACAGTC CTCCGCTTATTGATATGC)을 기반으로 하는 ITS3-4 primer를 사용하여 1차 PCR을 진행하였고, Nextra XT index kit를 사용하여 Barcode를 붙이는 2차 PCR을 통해 라이브 러리를 제작한다. 정제된 $\mathrm{PCR}$ 산물은 동량 모아서 TapeStation DNA screentape D1000(Agilent)으로 증폭산물 의 길이와 농도를 측정하였다. 최종 PCR 산물은 차세대염 기서열 분석인 MiSeq ${ }^{\mathrm{TM}}$ platform(Illumina, San Diego, USA) 
를 사용하여 제조사의 매뉴얼에 따라 Macrogen Inc.(Seoul, Korea)에서 수행하였다.

\section{외부 제조환경 조사}

본 연구에서는 지역별 고추장 제조업체의 내외부 제조환 경 조사항목으로 항아리 속 품온, 대기온도와 습도를 파악 했다. 이를 위해 각각의 업체에 항아리 높이 이상의 구간에 소형기상기록장치(HOBO Data Loggers, U23-003, Onset)를 설치하여 항아리 속 품온 $\left({ }^{\circ} \mathrm{C}\right)$, 대기온도 $\left({ }^{\circ} \mathrm{C}\right)$, 상대습도 $(\%)$ 를 측정하였다. 각 지역별 자체 풍향의 영향을 최소화하기 위 해 2시간 간격으로 2018년 4월부터 2019년 2월까지 온습도 결과를 측정한 후 각 일자의 해당 온습도를 최고, 평균, 최저로 구분하여 지역별, 발효기간별 비교분석하였다.

\section{통계 분석}

모든 실험은 시험항목에 따라 2-3회 반복 실험하여 평균 과 표준편차로 나타내었고, 실험값에 대한 통계분석은 SAS
9.2 program(SAS Institute Inc., Cary, NC, USA)을 이용하여 통계처리 하였으며, Duncan's multiple range test 방법과 t-test를 이용하여 평균값 간에 유의성을 검정하였다 $(\mathrm{p}<0.05)$. XLSTAT ver. 2017.5.05(Addinsoft, NewYork, NY, USA)을 이용하여 고추장 시료의 품질, 미생물 군집, 외부환 경 분석의 평균값을 통해 발효기간에 따라 각 권역별 고추 장 시료들 간의 상관성을 파악하기 위해 주성분분석 (Principal component analysis, PCA)을 실시하였다.

\section{결과 및 고찰}

\section{수분 및 염도}

전통방식으로 제조한 고추장을 8 개 권역 56개 생산업체 에서 수집하여 1 년간 발효기간 동안 품질 및 외부환경 변화 를 조사하고 그 관련성을 살펴보고자 하였다. 먼저 발효기 간에 따른 고추장의 수분 함량 변화는 Fig 1에 제시하였다.
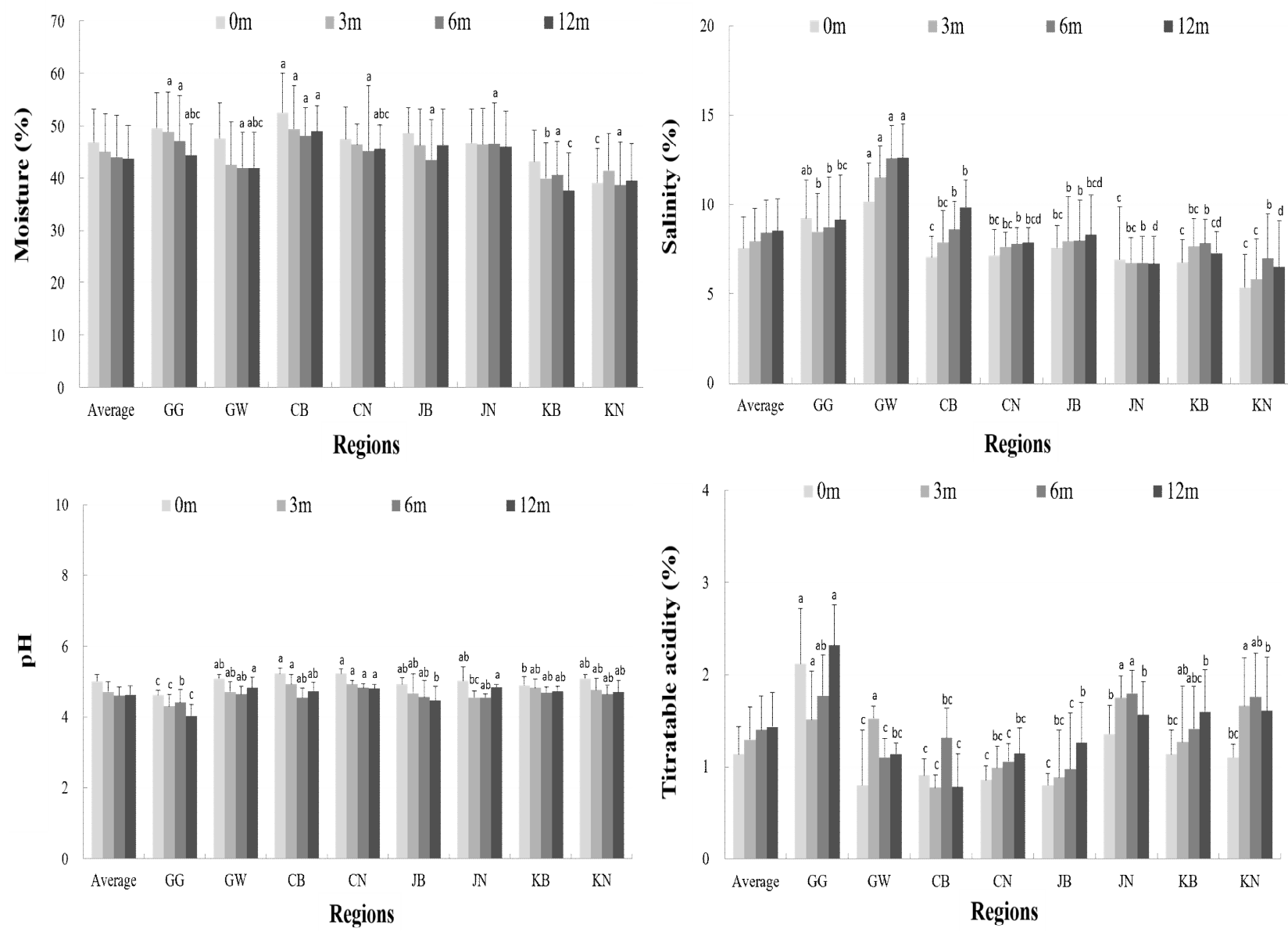

Fig. 1. Change on the contents of moisture, salinity, $\mathrm{pH}$ and titratable acidity of Gochujang produced by 8 regional rural during fermentation period (month).

GG, Gyeonggi-do; GW, Gangwon-do; CB, Chungcheongbuk-do; CN, Chungcheongnam-do; JB, Jeollabuk-do; JN, Jeollanam-do; KB, Gyeongsangbuk-do, KN, Gyeongsangnam-do. Values represent the means \pm SD. Any means in 8 region $(a-d)$ at the same fermentation period followed by different letters are significantly $(\mathrm{p}<0.05)$ different by Duncan's multiple range test. 
전체적으로 고추장의 수분 함량은 발효기간이 경과함에 따라 점차 감소하는 경향을 보였고, 평균적으로 담금 직후 $46.87 \pm 7.09 \%$, 발효 3 개월 차에 $45.16 \pm 7.16$, 발효 6 개월 차에 $44.00 \pm 8.07$, 그리고 발효 12 개월에는 $43.80 \pm 7.17$ 로 수분함 량이 낮아지는 경향을 보였다. 전체 평균값보다 같거나 높 은 수분함량을 나타낸 고추장은 경기도, 충청북도, 충청남 도 지역에서 제조된 것이고, 평균값보다 낮은 것은 경상북 도, 경상남도의 것으로 나타났으나 발효기간별 권역 간 비 교 시 뚜렷한 통계학적 유의성은 나타나지 않았다. 그러나 이들 고추장들의 수분함량은 전통식품 규격기준(3)에서 제 시하고 있는 $50 \%$ 이하의 규정에 충족하고 있어, 본 연구를 위해 수집된 고추장들은 모두 적합한 것으로 사료된다. 비 록 몇몇 시료들이 담금 초기 수분함량이 약간 높았지만 발효기간이 경과됨에 따라 점차 감소되어 지역별 수분함량 의 변화가 품질에 그다지 큰 영향을 주지 않는 것으로 판단 된다. 선행 연구결과와 비교해보면 수분함량은 숙성기간이 경과함에 따라 증가한다는 보고(12)도 있지만, 본 연구결과 와 유사하게 숙성기간이 경과함에 따라 감소하는 경향을 나타낸 보고도 있다(15).

본 연구에서 고추장의 발효기간에 따른 염도 변화는 Fig. 1 에 나타내었다. 발효기간에 따른 전체 고추장의 염도 평균 값은 $7.52 \pm 2.21 \%, 7.95 \pm 2.26,8.41 \pm 2.45$, 그리고 $8.53 \pm 2.57$ 로 점차 높아졌다. 지역별 염도값을 살펴보면 강원도의 경 우만 $10 \%$ 이상의 높은 값을 보였고, 나머지 지역의 경우 $10 \%$ 이하로 평균값과 유사하거나 낮은 값을 나타내었는데, 특히 전라남도와 경상남도 고추장의 경우 1 년 숙성 후 염도 가 각각 $6.69 \pm 2.27 \%$ 와 $6.51 \pm 1.20$ 로 통계학적으로 유의차 있게 낮은 값을 보였다. 그러나 타 지역제품에 비해 낮긴 하지만, 국민 다소비식품으로 선정된 고추장들의 식염함량 이 5.9-7.0\%의 범위로 나타나 오히려 시판 고추장과는 유사 한 경향을 나타내었다(22).

\section{$\mathrm{pH}$ 및 산도}

고추장의 $\mathrm{pH}$ 와 산도 측정 결과는 Fig. 1 에 나타내었다. 발효기간에 따른 고추장의 평균 $\mathrm{pH}$ 는 담금 직후 $5.01 \pm 0.30$, 발효 3개월째 $4.71 \pm 0.34$, 발효 6 개월째 $4.61 \pm 0.26$, 그리고 발효 12 개월에는 $4.63 \pm 0.34$ 으로 발효기간이 경과함에 따라 낮아졌는데, 특히 경기도와 전라북도에서 제조한 발효 12 개월째의 고추장의 경우 $\mathrm{pH}$ 값이 각각 $4.03 \pm 0.13$ 과 $4.48 \pm 0.14$ 로 다른 지역의 고추장에 비해 조금 낮은 값을 보였는데 경기도의 경우 발효기간 내내 통계적인 유의성을 나타내었다(p<0.05). 이는 Kwon 등(15)의 보고에 따르면 고추장의 $\mathrm{pH}$ 가 발효 0 주차에서 5.2-5.5로 나타났다가 발효 6주차에는 4.8-5.1로 숙성기간이 지남에 따라 점차 낮아져 본 연구결과와 유사한 경향을 보였다(23).

전체 고추장의 산도 평균값은 담금 직후 $1.13 \pm 0.50 \%$, 발효 3 개월째 $1.30 \pm 0.52$, 발효 6 개월째 $1.40 \pm 0.48$, 그리고
발효 12 개월째 $1.43 \pm 0.58$ 를 나타내어 기간에 따라 약간 증 가하는 경향을 보였는데, 타 지역에 비해 경기도 고추장의 산도 값은 통계적인 유의차가 있게 높은 값을 나타내었다 $(\mathrm{p}<0.05)$. 전체적으로 고추장의 $\mathrm{pH}$ 변화보다 산도 값의 변 화가 지역별로 조금 더 편차가 크게 보였다. 이와 같은 결과 는 다른 연구자의 보고에서도 팥고추장의 산도가 0 주차에 1.1-2.3\%이었다가 발효 6주차에는 6.0-6.4\%으로 발효기간 에 따라 점차 높아졌다고 언급하였고(23), Lee 등(17)의 연 구결과에서도 적정산도 측정결과가 $\mathrm{pH}$ 변화와 반대로 저 장기간 및 온도가 증가할수록 유의적으로 증가함을 보여줘 본 연구결과와 유사한 경향을 나타내었다.

\section{환원당 및 아미노태 질소}

전국에서 수집한 전통식 고추장의 환원당 함량과 아미노 태 질소 함량의 변화는 Fig. 2 에 제시하였다. 8 개도 권역별 7 개 업체의 평균 환원당 함량은 담금 직후 $16.46 \pm 7.63 \%$,
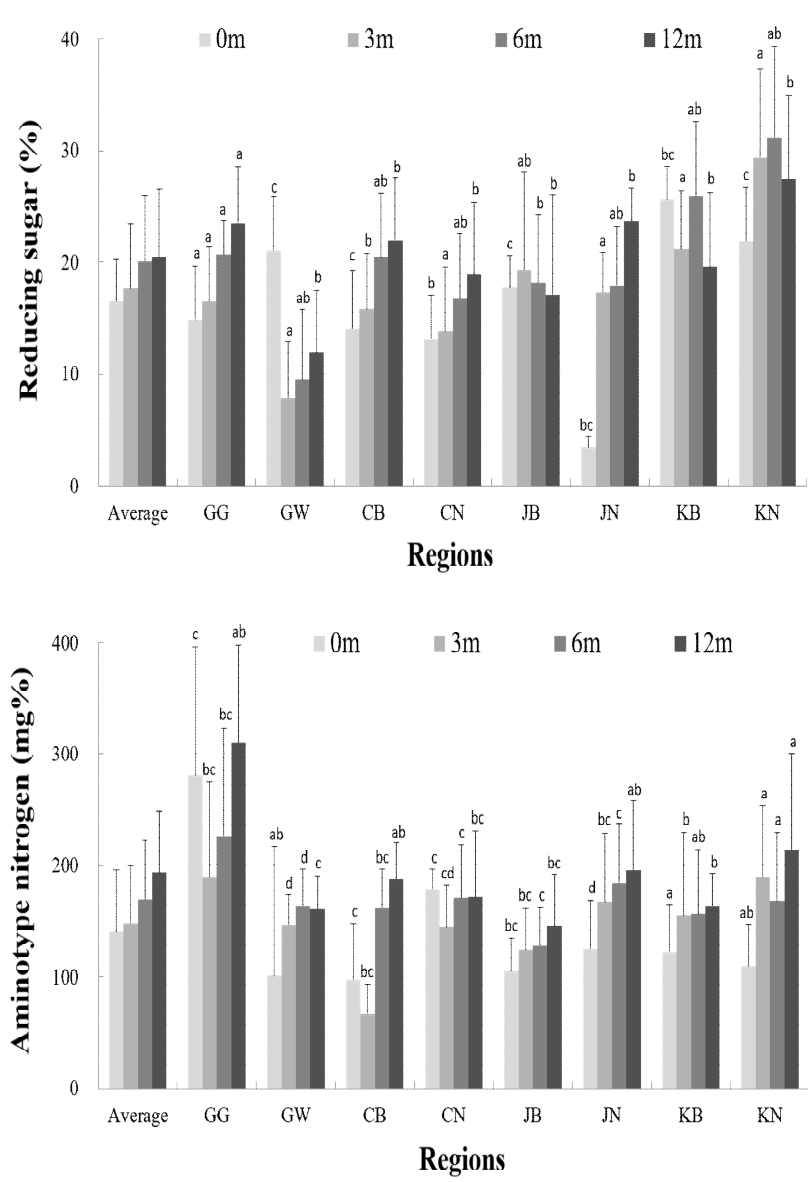

Fig. 2. Change on the contents of reducing sugar and amino-type nitrogen of Gochujang produced by 8 regional rural during fermentation period (month).

GG, Gyeonggi-do; GW, Gangwon-do; CB, Chungcheongbuk-do; CN, Chungcheongnam-do; JB, Jeollabuk-do; JN, Jeollanam-do; KB, Gyeongsangbuk-do, KN, Gyeongsangnam-do. Values represent the means \pm SD. Any means in 8 region (a-d) at the same fermentation period followed by different letters are significantly $(\mathrm{p}<0.05)$ different by Duncan's multiple range test. 
발효 3개월째 $17.64 \pm 7.92$, 발효 6개월째 20.07 \pm 8.17 , 그리고 발효 12 개월째 $20.48 \pm 7.57$ 로 점차 높아지는 양상을 보였다. 그러나 경기도를 제외하고 나머지 지역들에서 제조한 고추 장의 환원당 함량은 대체적으로 발효기간이 경과함에 따라 약간 증가하는 값을 나타내었으나 통계적인 유의성은 낮았 다 $(\mathrm{p}<0.05)$.

그리고 고추장의 아미노태 질소 함량 역시 발효기간이 경과함에 따라 전국 평균적으로 담금직후 $140.06 \pm 78.00$ $\mathrm{mg} \%$, 발효 3개월째 $147.96 \pm 64.09$, 발효 6개월째 $170.11 \pm$ 61.00 , 그리고 발효 12 개월째 $198.68 \pm 87.11$ 로 점차 높아지 는 양상을 보였다. 권역별로 비교해보면 경기도, 전라남도, 경상남도 고추장의 아미노태 질소 함량이 강원도, 충청북 도, 전라북도, 경상북도 고추장의 아미노태 질소 함량보다 조금 더 높게 보였으나 통계적인 유의성은 낮았다. 특히 경기도 지역 고추장의 발효완료 후 아미노태 질소 함량은 7 개 업체 평균값이 $310.27 \pm 165.99 \mathrm{mg} \%$ 로 다른 지역에 비해 월등히 높게 나타났다. 본 연구결과는 고추장의 아미노태 질소의 경우 발효기간이 지남에 따라 증가하는 경향을 보인 다는 다른 연구자들의 결과와 유사하였고(23), 또한 전통식 품 표준규격(3) 상 고추장의 아미노태 질소 함량이 160 $\mathrm{mg} \%$ 이상으로 제시된 값에 부합되었다. 아미노태 질소의 함량은 고추장에 제조에 사용되는 재료들에 함유된 미생물 과 이들이 분비하는 단백질 분해효소의 활성에 의해 높아 져, 현재 고추장의 품질평가 기준 중 하나로 사용되고 있다 $(24,25)$. 반면 아미노태 질소 함량이 저장기간 및 온도에 따라 유의적으로 감소한다는 상이한 연구결과도 있었다 (17).

\section{색 도}

고추장의 색은 소비자의 품질평가 기준 중 중요한 요인 이며, 기호도와 큰 상관관계가 있는 것으로 보고되어 있다 (24). 본 연구에서 측정한 고추장의 색도 분석 결과는 Fig. 3 에 제시하였다. 전체 수집된 고추장의 명도(L, lightness) 평균값은 발효기간이 경과함에 따라 $26.16 \pm 9.27,25.29 \pm$ $9.19,22.92 \pm 9.32$, 그리고 $22.49 \pm 9.02$ 로 점차 낮아져 어두워 지는 경향을 보였다. 지역별로 살펴보면 발효완료 후 경기 도, 강원도 및 충청남도 충청북도 및 전라북도, 그리고 전라 남도, 경상북도 및 경상남도 지역 고추장 시료들 순으로 $\mathrm{L}$ 값은 통계적인 유의성 있게 높은 경향을 보였다( $<<0.05)$. 이들 중 충청북도와 전라북도 지역에서 제조된 고추장의 $\mathrm{L}$ 값은 발효초기보다 발효 후에 급격히 낮아져 타 지역의 고추장보다 밝기에 있어 큰 변화를 보였다. 적색도(a, redness)의 전체 평균값은 발효초기부터 발효가 완료되는 시점까지 $21.87 \pm 6.31,21.71 \pm 6.58,21.49 \pm 7.03$, 및 20.14 7.58 로 조금 낮아지는 경향을 보였고, 황색도(b, yellowness) 평균값은 $19.43 \pm 11.94,19.20 \pm 11.40,19.38 \pm 11.27,19.18 \pm$ 12.06 로 그다지 큰 변화를 나타내지 않았다. 그러나 지역별
로 살펴보면 전라남도와 경상북도 고추장의 경우 발효 12 개월째에 a 값은 $25.55 \pm 3.78$ 과 $25.71 \pm 2.52$, b 값은 $27.16 \pm$ 5.12 와 $38.37 \pm 2.65$ 로 다른 지역의 고추장보다 높았는데 통
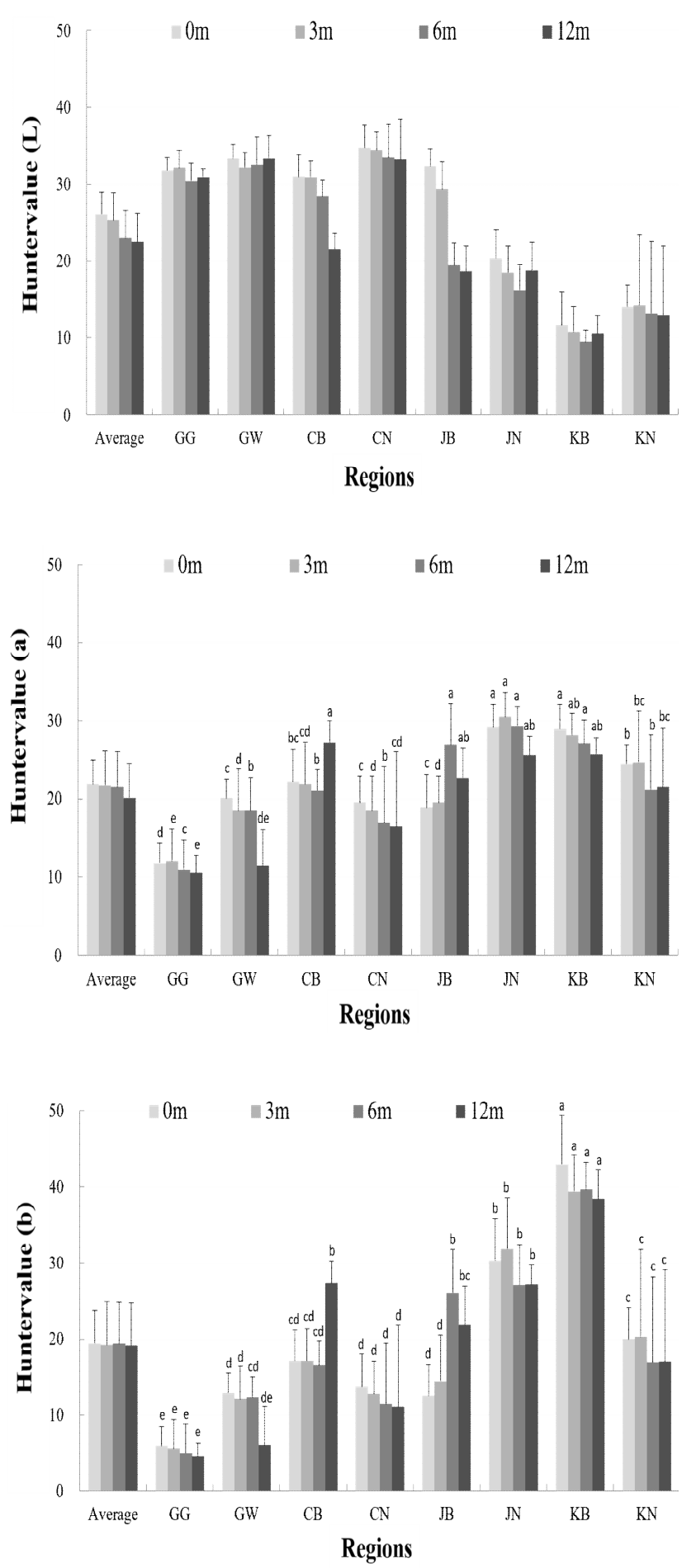

Fig. 3. Change on color of Gochujang produced by 8 regional rural during fermentation period (month).

GG, Gyeonggi-do; GW, Gangwon-do; CB, Chungcheongbuk-do; CN Chungcheongnam-do; JB, Jeollabuk-do; JN, Jeollanam-do; KB, Gyeongsangbuk-do, KN, Gyeongsangnam-do. L, lightness; a, redness; b, yellowness. Values represent the means \pm SD. 
계적으로 유의성은 낮았다. Lee 등(17)의 보고에서는 고추 장 표면색도가 저장기간이 경과할수록 $\mathrm{L}, \mathrm{a}, \mathrm{b}$ 값 모두 낮아 져 저장 초기보다 큰 차이를 보였다는 보고와 일부 지역을 제외하고 어느 정도 유사한 경향을 나타내었다.

\section{미생물 생균수}

전국 지역에서 제조된 전통식 고추장의 미생물 생균수 변화를 측정한 결과는 Table 1 과 같다. 평균적으로 총균수 는 발효기간에 따라 담금 직후 $6.50 \pm 1.29 \log \mathrm{CFU} / \mathrm{g}$ 에서 발효 12 개월째에 $8.15 \pm 0.88 \log \mathrm{CFU} / \mathrm{g}$ 로 그 수가 높아졌고, 지역별로는 경기도의 7개 업체 고추장의 평균값이 $8.23 \pm$ $1.33 \log \mathrm{CFU} / \mathrm{g}$ 으로 가장 높은 수를 나타낸 반면, 경상남도 고추장의 총균수는 $7.11 \pm 0.63 \log \mathrm{CFU} / \mathrm{g}$ 로 가장 낮은 수로 계수되었지만 통계적 유의성은 없었다. 대장균군은 발효 초기에 일부 지역 고추장에서 높게 검출되었으나, 발효가 완료된 후 모든 최종 제품에서는 통계적 유의성 있게 검출 되지 않았다. 바실러스 세레우스의 경우 국내 장류식품 중 기준규격에서 $10,000 \mathrm{CFU} / \mathrm{g}$ 이하로 관리하고 있는데(2), 본 연구에서 사용한 배양배지로는 8 개 권역별 7 개 업체에
서 제조된 고추장 시료들에서 발효초기 1.10-3.19 log $\mathrm{CFU} / \mathrm{g}$, 발효 완료 후 1.00-2.53 $\log \mathrm{CFU} / \mathrm{g}$ 수준으로 낮게 검출되어 모든 시료가 기준에 부합되었다. 효모의 경우 지 역 및 업체별로 편차가 커 발효기간에 따른 변화를 예측할 수는 없었지만, 전라남도와 경상북도의 고추장에서는 다른 지역에 비해 높은 수로 검출되었고, 경기도와 경상남도의 고추장에서 가장 낮게 검출되었는데 두 그룹 간에 통계적 유의성은 높았다. 각 권역별 수집한 고추장 내 곰팡이 수는 대체적으로 발효가 진행됨에 따라 그 수가 점차 감소되는 경향을 보였고, 발효 초기의 경우 강원도와 경상북도의 고 추장에서 가장 높은 수를 보였다가 점차 감소된 반면, 경기 도 고추장에서는 전혀 곰팡이가 검출되지 않았는데 이들 결과들은 통계학적으로 뚜렷한 차이를 나타내지는 않았다. Lee 등(17)의 결과에서도 저장기간 중 미생물의 변화는 대 체적으로 저장기간이 증가할수록 감소 경향을 보였고, 특 히 곰팡이는 전혀 검출되지 않았다고 보고하여 본 연구와 유사한 결과를 나타내었다. 이와 같은 미생물 변화는 고추 장에서 수분활성도, 수소이온 농도, 염 등이 미생물의 생육 인자들로 작용하여, 발효가 진행되면서 산도가 높아짐에

Table 1. Aerobic bacteria, coliform, B. cereus, yeast and fungi cell numbers of Gochujang produced by 8 regional rural during fermentation period

\begin{tabular}{|c|c|c|c|c|c|c|c|c|c|c|}
\hline \multirow{2}{*}{ Items } & \multirow{2}{*}{$\begin{array}{l}\text { Fermentation } \\
\text { period }\end{array}$} & \multicolumn{9}{|c|}{ Gochujang group (Log CFU/g) } \\
\hline & & GG & GW & $\mathrm{CB}$ & $\mathrm{CN}$ & $\mathrm{JB}$ & $\mathrm{JN}$ & $\mathrm{KB}$ & $\mathrm{KN}$ & Average \\
\hline \multirow{4}{*}{$\begin{array}{l}\text { Aerobic } \\
\text { bacteria }\end{array}$} & $0 \mathrm{~m}$ & $6.22 \pm 1.32^{\mathrm{Bb}}$ & $7.36 \pm 0.94^{\mathrm{Aa}}$ & $7.86 \pm 0.88^{\mathrm{Aa}}$ & $8.20 \pm 0.42^{\mathrm{Aa}}$ & $7.78 \pm 0.82^{\mathrm{Aa}}$ & $7.63 \pm 0.73^{\mathrm{Aa}}$ & $7.60 \pm 0.43^{\mathrm{ABa}}$ & $5.86 \pm 2.17^{\mathrm{ABb}}$ & $6.50 \pm 1.29$ \\
\hline & $3 \mathrm{~m}$ & $8.08 \pm 1.32^{\mathrm{ABa}}$ & $8.26 \pm 0.55^{\mathrm{Aa}}$ & $7.72 \pm 0.81^{\mathrm{Aa}}$ & $7.49 \pm 0.81^{\mathrm{Ba}}$ & $7.51 \pm 0.64^{\mathrm{Aa}}$ & $7.42 \pm 0.79^{\mathrm{Aa}}$ & $7.43 \pm 0.49^{\mathrm{Ba}}$ & $5.33 \pm 1.79^{\mathrm{ABb}}$ & $6.92 \pm 1.23$ \\
\hline & $6 \mathrm{~m}$ & $8.23 \pm 1.32^{\mathrm{Aa}}$ & $8.08 \pm 0.53^{\mathrm{Aa}}$ & $7.80 \pm 0.84^{\mathrm{Aa}}$ & $7.32 \pm 0.64^{\mathrm{Ba}}$ & $7.47 \pm 0.74^{\mathrm{Aa}}$ & $7.54 \pm 0.94^{\mathrm{Aa}}$ & $8.09 \pm 0.38^{\mathrm{Aa}}$ & $4.85 \pm 1.56^{\mathrm{Bb}}$ & $7.26 \pm 1.33$ \\
\hline & $12 \mathrm{~m}$ & $8.23 \pm 1.33^{\mathrm{ABa}}$ & $7.92 \pm 0.58^{\mathrm{Aa}}$ & $7.31 \pm 1.03^{\mathrm{Aa}}$ & $7.57 \pm 0.53^{\mathrm{ABa}}$ & $7.25 \pm 0.66^{\mathrm{Aa}}$ & $8.00 \pm 1.31^{\mathrm{Aa}}$ & $7.92 \pm 0.46^{\mathrm{ABa}}$ & $7.11 \pm 0.63^{\mathrm{Aa}}$ & $8.15 \pm 0.88$ \\
\hline \multirow{4}{*}{ Coliform } & $0 \mathrm{~m}$ & $5.43 \pm 1.23^{\mathrm{Aa}}$ & $0.00 \pm 0.00^{\mathrm{Ac}}$ & $0.00 \pm 0.00^{\mathrm{Ac}}$ & $0.00 \pm 1.47^{\mathrm{Ab}}$ & $0.00 \pm 0.00^{\mathrm{Ac}}$ & $1.08 \pm 1.42^{\mathrm{Abc}}$ & $0.84 \pm 2.21^{\mathrm{Abc}}$ & $0.97 \pm 1.68^{\mathrm{Abc}}$ & $0.92 \pm 2.03$ \\
\hline & $3 \mathrm{~m}$ & $2.71 \pm 0.00^{\mathrm{Ba}}$ & $0.00 \pm 0.00^{\mathrm{Aa}}$ & $0.00 \pm 0.00^{\mathrm{Aa}}$ & $0.00 \pm 0.00^{\mathrm{Ba}}$ & $0.00 \pm 0.00^{\mathrm{Aa}}$ & $0.00 \pm 0.00^{\mathrm{Ba}}$ & $0.49 \pm 1.29^{\mathrm{Aa}}$ & $0.00 \pm 0.00^{\mathrm{Aa}}$ & $0.69 \pm 0.46$ \\
\hline & $6 \mathrm{~m}$ & $1.71 \pm 0.00^{\mathrm{Ba}}$ & $0.00 \pm 0.00^{\mathrm{Aa}}$ & $0.00 \pm 0.00^{\mathrm{Aa}}$ & $0.00 \pm 0.00^{\mathrm{Ba}}$ & $0.00 \pm 0.00^{\mathrm{Aa}}$ & $0.00 \pm 0.00^{\mathrm{Ba}}$ & $0.55 \pm 1.47^{\mathrm{Aa}}$ & $0.00 \pm 0.00^{\mathrm{Aa}}$ & $0.92 \pm 0.52$ \\
\hline & $12 \mathrm{~m}$ & $0.00 \pm 0.00^{\mathrm{Ba}}$ & $0.00 \pm 0.00^{\mathrm{Aa}}$ & $0.00 \pm 0.00^{\mathrm{Aa}}$ & $0.00 \pm 0.00^{\mathrm{Ba}}$ & $0.00 \pm 0.00^{\mathrm{Aa}}$ & $0.00 \pm 0.00^{\mathrm{Ba}}$ & $0.00 \pm 0.00^{\mathrm{Aa}}$ & $0.00 \pm 0.00^{\mathrm{Aa}}$ & $1.33 \pm 0.00$ \\
\hline \multirow{4}{*}{ B. cereus } & $0 \mathrm{~m}$ & $3.00 \pm 0.51^{\mathrm{Aab}}$ & $1.10 \pm 1.39^{\mathrm{Abc}}$ & $2.60 \pm 1.42^{\mathrm{Ac}}$ & $1.84 \pm 1.41^{\mathrm{Aabc}}$ & $3.19 \pm 1.12^{\mathrm{Aa}}$ & $2.54 \pm 1.44^{\mathrm{Aab}}$ & $2.29 \pm 2.33^{\mathrm{Aabc}}$ & $1.38 \pm 1.41^{\mathrm{Abc}}$ & $1.79 \pm 1.58$ \\
\hline & $3 \mathrm{~m}$ & $3.14 \pm 1.04^{\mathrm{Aa}}$ & $1.65 \pm 1.71 \mathrm{~A}^{\mathrm{abc}}$ & $2.24 \pm 0.85^{\mathrm{Ac}}$ & $1.17 \pm 0.85^{\mathrm{Aabc}}$ & $2.24 \pm 1.19^{\mathrm{ABab}}$ & $1.25 \pm 1.25 \mathrm{~A}^{\mathrm{abc}}$ & $1.49 \pm 2.06^{\mathrm{Aabc}}$ & $0.80 \pm 0.81^{\mathrm{Abc}}$ & $1.89 \pm 1.41$ \\
\hline & $6 \mathrm{~m}$ & $2.00 \pm 1.47^{\mathrm{Aa}}$ & $1.71 \pm 1.54^{\mathrm{Aa}}$ & $2.00 \pm 1.18^{\mathrm{Aa}}$ & $1.44 \pm 1.56^{\mathrm{Aa}}$ & $1.52 \pm 1.45^{\mathrm{Ba}}$ & $1.57 \pm 1.67^{\mathrm{Aa}}$ & $1.89 \pm 2.09^{\mathrm{Aa}}$ & $1.09 \pm 1.14^{\mathrm{Aa}}$ & $2.14 \pm 1.48$ \\
\hline & $12 \mathrm{~m}$ & $1.37 \pm 1.60^{\mathrm{Aa}}$ & $1.59 \pm 1.43^{\mathrm{Aa}}$ & $2.53 \pm 1.37^{\mathrm{Aa}}$ & $1.73 \pm 1.42^{\mathrm{Aa}}$ & $2.02 \pm 1.47^{\mathrm{ABa}}$ & $1.00 \pm 1.54^{\mathrm{Aa}}$ & $2.27 \pm 1.81^{\mathrm{Aa}}$ & $1.70 \pm 1.51^{\mathrm{Aa}}$ & $2.91 \pm 1.49$ \\
\hline \multirow{4}{*}{ Yeast } & $0 \mathrm{~m}$ & $1.19 \pm 1.36^{\mathrm{Ac}}$ & $3.57 \pm 0.46^{\mathrm{Aab}}$ & $0.00 \pm 0.00^{\mathrm{Bc}}$ & $4.04 \pm 1.50^{\mathrm{Aa}}$ & $3.34 \pm 1.14^{\mathrm{Aab}}$ & $2.47 \pm 1.39^{\mathrm{Ab}}$ & $3.40 \pm 1.04^{\mathrm{Aab}}$ & $0.78 \pm 0.83^{\mathrm{Ac}}$ & $2.09 \pm 1.78$ \\
\hline & $3 \mathrm{~m}$ & $0.41 \pm 1.38^{\mathrm{Ab}}$ & $2.13 \pm 1.82^{\mathrm{Aab}}$ & $2.80 \pm 1.37^{\mathrm{ABab}}$ & $0.86 \pm 1.37^{\mathrm{Bab}}$ & $0.92 \pm 1.30^{\mathrm{Bab}}$ & $0.64 \pm 1.06^{\mathrm{Bab}}$ & $2.41 \pm 1.69^{\mathrm{Aa}}$ & $0.66 \pm 1.22^{\mathrm{Aab}}$ & $1.54 \pm 1.55$ \\
\hline & $6 \mathrm{~m}$ & $0.44 \pm 1.11^{\mathrm{Ac}}$ & $2.42 \pm 2.55^{\mathrm{Aab}}$ & $3.42 \pm 1.92^{\mathrm{Aabc}}$ & $0.86 \pm 1.48^{\mathrm{Bbc}}$ & $0.60 \pm 0.86^{\mathrm{Bbc}}$ & $3.16 \pm 1.81^{\mathrm{Aa}}$ & $3.68 \pm 1.62^{\mathrm{Aa}}$ & $0.20 \pm 0.53^{\mathrm{Ac}}$ & $2.31 \pm 1.96$ \\
\hline & $12 \mathrm{~m}$ & $0.00 \pm 0.00^{\mathrm{Ac}}$ & $2.64 \pm 1.82^{\mathrm{Aab}}$ & $2.15 \pm 1.42^{\mathrm{ABbc}}$ & $1.23 \pm 1.89^{\mathrm{Bbc}}$ & $0.00 \pm 0.00^{\mathrm{Bc}}$ & $3.32 \pm 1.68^{\mathrm{Aa}}$ & $3.22 \pm 1.77^{\mathrm{Aa}}$ & $0.37 \pm 0.77^{\mathrm{Ac}}$ & $2.77 \pm 1.84$ \\
\hline \multirow{4}{*}{ Fungi } & $0 \mathrm{~m}$ & $0.00 \pm 0.00^{\mathrm{Ab}}$ & $2.83 \pm 1.20^{\mathrm{Aa}}$ & $0.00 \pm 0.00^{\mathrm{Bb}}$ & $1.46 \pm 1.92^{\mathrm{Aab}}$ & $1.64 \pm 0.16^{\mathrm{Aa}}$ & $1.47 \pm 1.47^{\mathrm{Aab}}$ & $2.63 \pm 2.47^{\mathrm{Aa}}$ & $1.51 \pm 0.89^{\mathrm{Aab}}$ & $1.28 \pm 1.58$ \\
\hline & $3 \mathrm{~m}$ & $0.00 \pm 0.73^{\mathrm{Aa}}$ & $1.14 \pm 1.47^{\mathrm{Ba}}$ & $2.74 \pm 1.04^{\mathrm{ABa}}$ & $0.06 \pm 1.04^{\mathrm{Ba}}$ & $3.37 \pm 6.94^{\mathrm{Aa}}$ & $0.46 \pm 0.76^{\mathrm{Aa}}$ & $2.03 \pm 2.59^{\mathrm{Aa}}$ & $0.42 \pm 0.92^{\mathrm{Aa}}$ & $1.47 \pm 2.78$ \\
\hline & $6 \mathrm{~m}$ & $0.00 \pm 0.00^{\mathrm{Aa}}$ & $0.86 \pm 1.47^{\mathrm{Ba}}$ & $0.00 \pm 0.00^{\mathrm{Ba}}$ & $0.24 \pm 0.62^{\mathrm{Ba}}$ & $0.09 \pm 0.21^{\mathrm{Aa}}$ & $0.47 \pm 0.89^{\mathrm{Aa}}$ & $1.05 \pm 1.80^{\mathrm{Aa}}$ & $0.56 \pm 1.11^{\mathrm{Aa}}$ & $1.03 \pm 1.00$ \\
\hline & $12 \mathrm{~m}$ & $0.00 \pm 1.30^{\mathrm{Aa}}$ & $0.60 \pm 1.58^{\mathrm{Ba}}$ & $2.01 \pm 1.38^{\mathrm{Aa}}$ & $0.00 \pm 0.00^{\mathrm{Ba}}$ & $0.00 \pm 0.00^{\mathrm{Aa}}$ & $0.29 \pm 0.76^{\mathrm{Aa}}$ & $1.11 \pm 1.28^{\mathrm{Aa}}$ & $0.50 \pm 0.85^{\mathrm{Aa}}$ & $1.83 \pm 1.08$ \\
\hline
\end{tabular}

${ }^{1)}$ GG, Gyeonggi-do; GW, Gangwon-do; CB, Chungcheongbuk-do; CN, Chungcheongnam-do; JB, Jeollabuk-do; JN, Jeollanam-do; KB, Gyeongsangbuk-do: KN, Gyeongsangnam-do.

${ }^{2)}$ Any means in the same fermentation time $(\mathrm{A}-\mathrm{B})$ or region $(\mathrm{a}-\mathrm{c})$ followed by different letters are significantly $(\mathrm{p}<0.05)$ different by Duncan's multiple range test. 
따라 고추장 내 영양분의 고갈로 인해 미생물의 증식이 저하된 것으로 사료된다(26).

\section{미생물군집 분석(Next Generation Sequencing, NGS)}

8개 지역 권역에서 2018년도에 제조한 전통식 고추장 시료를 담금 직후와 1년간 발효시킨 후 미생물 군집 변화를 살펴보기 위하여 진균과 세균의 군집 분석을 수행하여 Fig. 4에 나타내었다. 고추장의 진균 분포도는 문(phylum) 수준 에서는 Ascomycota문(Fig. 4A, green color)이 우점균을 형 성하고 있었는데, unidentified된 미생물(Fig. 4A, grey color) 을 제외하고 Basidiomycota문과 Mucoromycota문 역시 고 추장 내 미생물 군집을 형성하고 있었다. 가장 두드러진 Ascomycota문의 경우 지역 구분 없이 발효 초기에는 45.2-3.9\% 수준을 보였다가 발효 후에는 50.1-96.6\% 범위로 높아짐을 알 수 있었다. 고추장 내 Basidiomycota문과

(A)
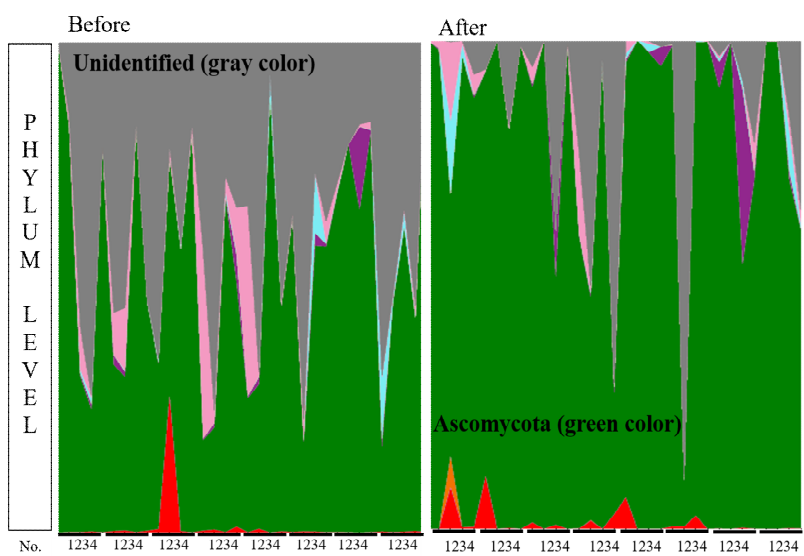

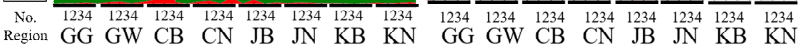

(C)

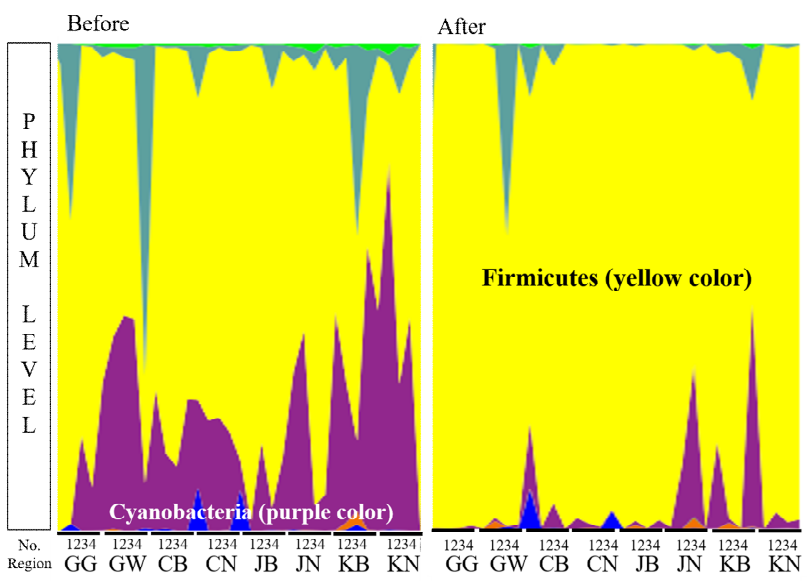

Mucoromycota문은 발효 유무와 상관없이 $0.0-11.4 \%$ 와 0.0-3.6\% 수준으로 포함되고 있었으나, 이번 실험에서 사용 한 고추장 시료들에서는 곰팡이 중 Ascomycota문과 unidentified문이 가장 우세하였다. 곰팡이 외에도 일부 시 료에서 Candida, Issatchenkia, 그리고 Zygosaccharomyces속 등의 효모도 검출되었으나 그 구성비가 높지 않았다. 속 (Genus) 수준에서는 unidentified 진균(Fig. 4B, brown color) 이 발효 후에 우세하였고, Aspergillus속(Fig. 4B, yellow color)이 발효 후 약간 감소하는 경향을 보였다. 호남 및 제주도 지역의 고추장의 진균 분포를 살펴본 연구(27)에서 두 지역이 공통으로 차지하는 우점균은 없었고, 전라남도 와 제주도의 경우 Aspergillus속과 Rhizopus속이 우세하였 고, 전라북도 고추장에서는 Zygosaccharomyces속이 우점 하고 있다고 보고한 결과와 강원도를 제외하고 대부분이 Aspergillus속이 우세하였다는 점에서 유사한 경향을 나타 내었다.

(B)

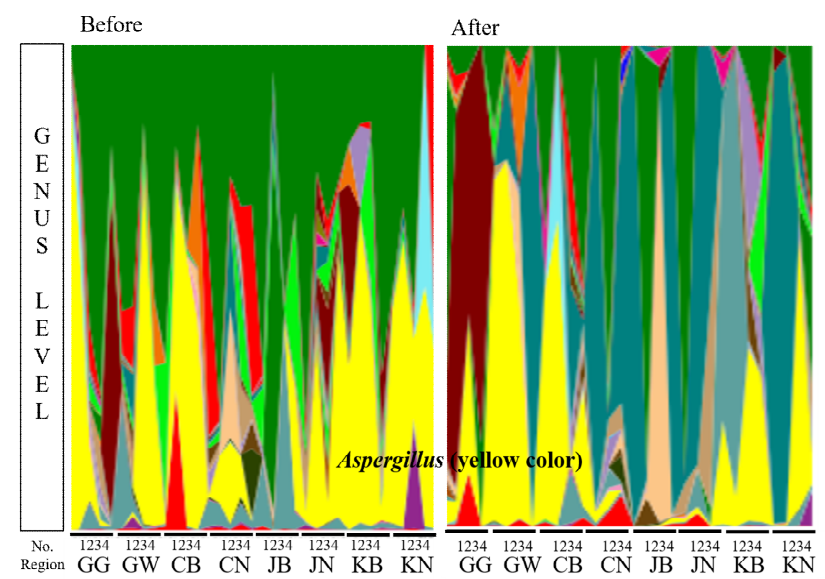

(D)

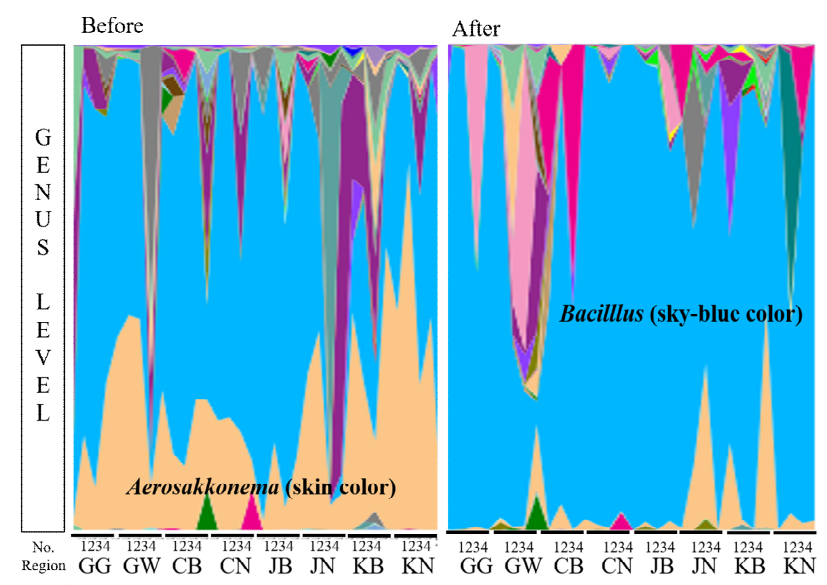

Fig. 4. Comparison of microbial community in Gochujang by using the next generation sequencing analysis. (A) Phylum and (B) Genus level of fungi, (C) Phylum and (D) Genus level of bacteria.

GG, Gyeonggi-do; GW, Gangwon-do; CB, Chungcheongbuk-do; CN, Chungcheongnam-do; JB, Jeollabuk-do; JN, Jeollanam-do; KB, Gyeongsangbuk-do, KN, Gyeongsangnam-do. Four samples by region was analyzed. 
전통식 고추장의 세균 분포도를 지역 구분 없이 보았을 때 문(phylum) 수준에서는 Firmicutes문(Fig. 4C, yellow color)이 발효 초기에는 45.0-87.0\% 수준으로 검출되었다 가, 발효 후에는 79.9-99.7\% 범위로 높아져 우점하고 있었 다. 그 다음으로 높았던 Cyanobacteria문(Fig. 4C, purple color)의 경우 발효초기에는 $10.8-51.6 \%$ 수준으로 시작하 여 발효 후에는 0.2-15.6\% 범위까지 낮아져, 이들 미생물의 변화가 고추장에서 큰 역할을 할 것으로 사료된다. 속 (Genus) 수준에서는 Aerosakkonema속(Fig. 4D, skin color) 이 발효 전과 달리 발효 후에 거의 사라지고, Bacilllus속 (Fig. 4D, sky-blue color)이 발효 후에 약간 증가하는 경향을 보이며 우점하고 있었다. Cho 등(27)은 호남 - 제주권의 고 추장 시료에서 전체 미생물 중 $80.2 \%$ 가 Bacillus속으로 우 점하고 있다고 보고하였는데, 본 연구에서도 발효 전에는 49.7\%, 발효 후에는 $73.7 \%$ 로 높은 빈도수를 보여 발효 후반 에 Bacillus속이 우세하다는 결과와 유사한 경향을 보였다.

\section{지역 및 발효기간에 따른 외부환경변화}

고추장의 제조환경조사를 위해 8개 지역별 7개 업체에서 항아리 품온과 외부의 온도, 습도를 관측하여 그 값을 $\mathrm{Max}$, Ave, Min으로 표시하여 Fig. 5A에 나타내었다. 먼저 내부 항아리의 품온은 여름철에 최대 경기 42.7 , 전남 40.9 , 강원 $40.4^{\circ} \mathrm{C}$ 순으로 외부온도와 비례하게 높은 반면 가장 낮은 곳은 충북 $\left(34.0^{\circ} \mathrm{C}\right)$ 과 전북 $\left(34.3^{\circ} \mathrm{C}\right)$ 지역 고추장이었다. 외부 환경조사에서 외기온도는 여름철에 최대로 경기 42.3 , 경남 42.0 , 충남 $41.5^{\circ} \mathrm{C}$ 순으로 높은 반면 항아리 품온과 마찬가지 로 충북 $\left(31.7^{\circ} \mathrm{C}\right)$ 과 전북 $\left(30.4^{\circ} \mathrm{C}\right)$ 지역은 가장 낮은 온도를 나타내었다. 외부 습도의 경우 충남, 전남, 경북, 경남 지역 의 경우 1 년 내내 $100 \%$ 로 높은 습도를 나타내었고, 경기와 강원의 경우 겨울철에만 높은 습도를 나타낸 반면, 충북과 전북의 경우 93.5-97.7 그리고 95.7-97.9\% 범위로 타 지역에 비해 습도의 변화가 크지 않은 특징을 보였다. 이들 두 지역 은 외부환경변화가 연중 그다지 크지 않아 그로인해 항아리 품온 역시 타 지역에 비해 높지 않은 것으로 사료된다.

\section{고추장의 품질 및 환경과의 상관관계}

전통식 고추장의 품질 및 외부환경 특성을 시각적으로 나타내고 이들 특성들 간에 상관성을 살펴보기 위하여 주성 분 분석을 실시한 결과 제 1 주성분과 2 주성분이 총 분산의 $49.90 \%$ 의 설명력을 갖는 것으로 분석되었다(Fig. 5B). 총 분산 중 $34.82 \%$ 를 설명한 제 1 주성분은 오른쪽 방향으로 품온, $\mathrm{pH}$, 외부온도, cyanobacteria 등의 변수가 감지되었고 이런 특성을 나타내는 시료들은 발효 전 담금 직후의 고추 장으로 분석되었다, 이와 반대인 왼쪽 방향으로는 염도,

(A)
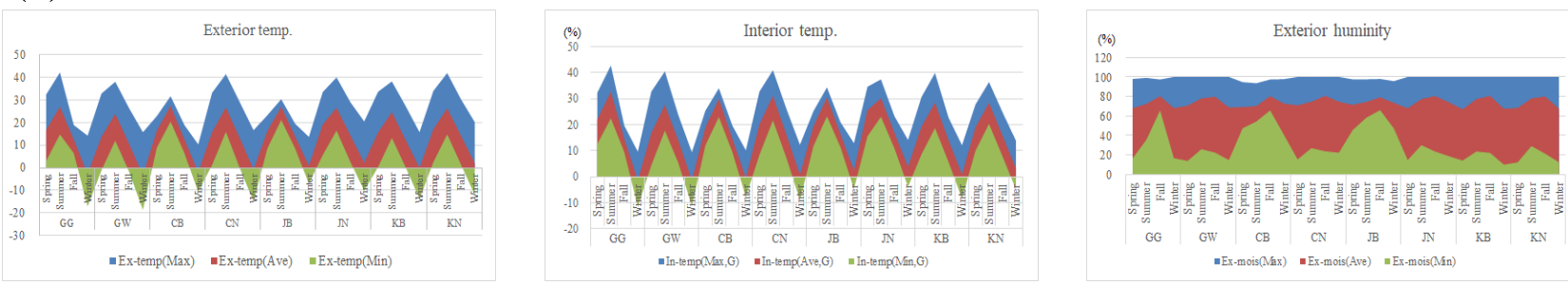

(B)
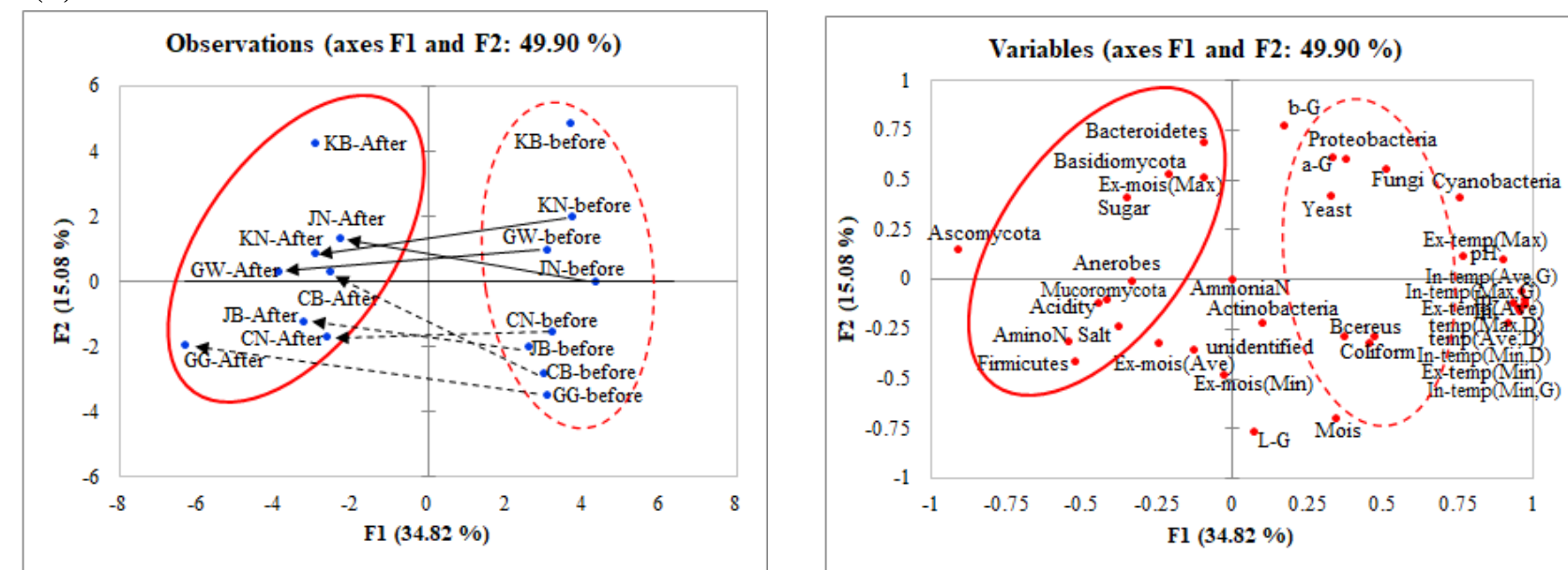

Fig. 5. The principal components analysis plots showing the relationships among the changes on components and exterior environment of Gochujang produced by 8 regional rural during fermentation period.

GG, Gyeonggi-do; GW, Gangwon-do; CB, Chungcheongbuk-do; CN, Chungcheongnam-do; JB, Jeollabuk-do; JN, Jeollanam-do; KB, Gyeongsangbuk-do, KN, Gyeongsangnam-do. Values represent the means \pm SD. 
산도, 환원당, 아미노태질소, 총균수, 외부습도, Firmicytes, Mucoromycot, Basidiomycota, Bacteroidetes문 등의 특성을 가진 요인들이 위치하였는데, 이런 특성을 나타내는 시료 들로는 1 년 간 발효 - 숙성된 고추장들이었다. 제 2 주성분은 전체데이터의 $15.08 \%$ 의 설명력을 보여주었는데 $\mathrm{Y}$ 축의 위 쪽 방향으로 염도, 아미노태질소, 총균수, 외부습도, Firmicytes, Mucoromycota 등의 요인들이 감지되었고, 발효 후 경기, 충북, 충남, 전북지역의 고추장들이 이러한 특성이 강한 것으로 분석된 반면, 강원, 전남, 경북, 경남지역의 고추장들은 이러한 특성이 약한 반대방향에 위치하였는데 산도, 환원당, 외부습도, Basidiomycota, Bacteroidetes문 등 의 특성이 강하게 나타났다. 결론적으로 지역 간 품질 및 외부환경 분석 간의 상관성 분석 결과 전통식 고추장은 발효전후에 따라 뚜렷한 차이를 보였고, 특히 발효 후 시료 들 간에도 경기, 충북, 전북, 충남지역 고추장들과. 강원, 전남, 경북, 경남 지역 고추장으로 나뉘었고, 이들을 구분하 는데 있어 성분들 중에는 아미노태질소, 염도와 산도, 환원 당이 상관관계를 나타냈고, 미생물 중에서는 Firmicutes와 Bacteriodes문, 외부환경요소 중에는 습도가 높은 상관성을 보여 발효기간 동안 지역별로 품질변화가 다르게 나타남을 알 수 있었다.

\section{요 약}

전통방식으로 제조한 고추장을 8 개 권역으로 구분하여 총 56 개 제조업체에서 시료 수집하여 1 년의 발효기간 동안 품질 및 외부환경 변화를 조사하고 그 관련성을 살펴보고자 하였다. 전체적으로 고추장의 수분 함량은 발효기간이 경 과함에 따라 점차 감소하는 경향을 보였고, 그로 인해염도 평균값은 발효 초기에 $7.52 \pm 2.21 \%$ 에서 발효 후 $8.53 \pm 2.57 \%$ 까지 점차 높아졌다. $\mathrm{pH}$ 는 담금 직후 $5.01 \pm 0.30$ 에서 발효 12 개월째에는 $4.63 \pm 0.34$ 로 조금 낮아져 이로 인한 고추장 의 산도는 $1.13 \pm 0.50 \%$ 에서 $1.43 \pm 0.58 \%$ 까지 약간 높은 값을 보였다. 환원당 함량은 발효기간이 경과함에 따라 발효초 기에 $16.46 \pm 7.63 \%$ 에서 발효 후 $20.48 \pm 7.57 \%$ 까지 증가하였 는데, 아미노태 질소 함량 역시 초기에 $140.06 \pm 78.00 \mathrm{mg} \%$ 에서 $198.68 \pm 87.11 \mathrm{mg} \%$ 까지 점차 높아지는 양상을 보였다. 발효기간에 따른 고추장의 색도 변화는 평균적으로 $\mathrm{L}$ 과 $\mathrm{a}$ 값은 발효초기보다 발효 후에 약간 감소하는 경향을 보인 반면 $b$ 값은 발효전후 그다지 큰 변화를 보이지 않았다. 발효 기간에 따라 담금 직후 $6.50 \pm 1.29 \log \mathrm{CFU} / \mathrm{g}$ 에서 발효 12 개 월째에 $8.15 \pm 0.88 \log \mathrm{CFU} / \mathrm{g}$ 로 그 수가 높아졌고, 곰팡이수 는 대체적으로 발효가 진행됨에 따라 그 수가 점차 감소되 는 경향을 보였다. 미생물군집 분석결과 고추장 내 세균의 경우 발효초기에 Firmicutes문과 Cyanobacteria문이 우세하 다가 발효 후에는 Firmicutes문만이 79.9-99.7\% 범위로 우점
하였다. 고추장 내 진균의 경우 발효 후에 50.1-96.6\% 범위 로 검출된 Ascomycota문 중에는 Aspergillus속이 가장 우세 하였다. 그리고 외부환경조사에서는 충청북도와 전라북도 지역이 연중 온도와 습도 변화가 그다지 크지 않았고, 특히 습도값은 여러 성분들 중 아미노태 질소, 염도, 산도 및 환원당과 상관성이 높게 나타났다.

\section{감사의 글}

본 연구는 농촌진흥청 공동연구사업(PJ013456)의 지원 에 의해 수행된 것으로 이에 감사드립니다.

\section{References}

1. KMA (2017) Weather information. Korea Meteorological Administration, Seoul, Korea

2. KFDA (2015) Korean Food Standards Codex. Korean Food and Drug Administration, Cheongju, Korea

3. NAQS (2012) Traditional Food Quality Certification System. National Agricultural Products Quality Management Service, Gimcheon, Korea, p 74

4. Shin DH, Kim DH, Choi U, Lim DK, Lim MS (1996) Studies on taste components of traditional Gochujang. Korean J Food Sci Technol, 28, 152-156

5. Shin DH, Kim DH, Choi U, Lim DK, Lim MS (1996) Studies on the physicochemical characteristics of traditional Gochujang. Korean J Food Sci Technol, 28, 157-161

6. Hwang JY, Jeong HP, Jang JS, Jang SJ, Kim JS (2017) Preparation and quality characterization of garlic Gochujang with Alaska pollock Therage chalcogramma Roe. Korean J Fish Aquat Sci, 50, 235-242

7. Choo JJ (2000) Anti-obesity effects of Gochujang in rats fed on a high-fat diet. Korean J Nutr, 33, 787-793

8. Park KY, Kong KR, Jung KO, Rhee SH (2001) Inhibitory effects of Gochujang extracts in the tumor formation and lung metastasis in mice. J Food Sci Nutr, 6, 187-191

9. Na SE, Seo KS, Choi JH, Song GS, Choi DS (1997) Preparation of low salt and functional Gochujang containing chitosan. Korean J Food Nutr, 10, 193-200

10. Lim SI, Choi SY, Cho GH (2006) Effects of functional ingredients addition on quality characteristics of Gochujang. Korean J Food Sci Technol, 38, 779-784

11. Ryu DG, Park SK, Jang YM, Song HS, Kim YM, Lee MS (2018) Changes in food quality characteristics of 
Gochujang by the addition of sea-tangle Saccharina japonica powder fermented by lactic acid bacteria. Korean J Fish Aquat Sci, 51, 213-220

12. Kim DH, Yang SE (2004) Fermentation characteristics of low salted Gochujang prepared with sub-materials. Korean J Food Sci Technol, 36, 97-104

13. Kim DH, Ahn BY, Park BH (2003) Effect of Lycium chinense fruit on the physicochemical properties of Gochujang. Korean J Food Sci Technol, 35, 461-469

14. Kim J, Kang SA (2018) Antioxidant effects of Gochujang with added Omija (Schizandra chinensis) by-product extract powder. Korean J Food Nutr, 31, 388-394

15. Kwon NR, Yoon HS, Kim IJ, Hong ST, Kim SY, Gil NY, Han NS, Eom HJ (2018) Quality characterization of red bean Gochujang prepared with different ratios of Meju. Korean J Food Nutr, 31, 751-759

16. Kim HS, Lee KY, Lee HG, Han O, Chang UJ (1997) Studies on the extension of the shelf-life of Gochujang during storage. J Korean Soc Food Sci Nutr, 26, 595-600

17. Lee KY, Kim HS, Lee HG, Han O, Chang UJ (1997) Studies on the prediction of the shelf-life of Gochujang through the physicochemical and sensory analyses during storage. J Korean Soc Food Sci Nutr, 26, 588-594

18. AOAC (2005) Official methods of analysis $\left(18^{\text {th }}\right.$ ed.). Association of Official Analytical Chemists, Washington DC, USA, p 970.59

19. Choi BY, Gil NY, Park SY, Kim SY (2016) Quality characteristics of Doenjang depending on various salt concentration during long-term fermentation period. Korean J Food Preserv, 23, 788-796
20. Gil NY, Choi BY, Park SY, Cho YS, Kim SY (2017) Physicochemical properties of Doenjang using grain type Meju fermented by Aspergillus oryzae and protease. Korean J Food Preserv, 24, $697-706$

21. AOAC (1990) Official Methods of Analysis (15 $5^{\text {th }}$ ed). Association of Official Analytical Chemists, Washington DC, USA, p 335

22. Korea Consumer Agency (2012) Report on quality test of Gochujang, commonly consumed food in Korea. Korea Consumer Agency, 22

23. Park ES, Heo JH, Ju JH, Park KY (2016) Changes in quality characteristics of Gochujang prepared with different ingredients and Meju starters. J Korean Soc Food Sci Nutr, 45, 880-888

24. Chae IS, Kim HS, Ko YS, Kang MH, Hong SP, Shin DB (2008) Effect of citrus concentrate on the physicochemical properties of Gochujang. Korean J Food Sci Technol, 40, 626-632

25. Park JM, Oh HI (1995) Changes in microflora and enzyme activities of traditional Gochujang Meju during fermentation. Korea J Food Sci Technol, 27, 56-62

26. Cho SH, Park HS, Jo SW, Yim EJ, Yang HY, Ha GS, Kim EJ, Yang SJ, Jeong DY (2017) Comparison of microbial community profiling on traditional fermented soybean products (Deonjang, Gochujang) produced in Jeonbuk, Jeonnam, and Jeju province area. Korean J Microbiol, 53, 39-48 